\title{
Closed-loop small bowel obstruction from lateral trocar site hernia following robotic sigmoid resection
}

\author{
Shinban Liu, Nicholas Morin, George Ferzli
}

Department of General Surgery, NYU Langone Medical Center, Brooklyn, New York, USA

Correspondence to Dr Shinban Liu,

shinban.liu@nyumc.org

Accepted 30 May 2018

Check for updates

To cite: Liu S, Morin N, Ferzli G. BMJ Case Rep Published Online First: [please include Day Month Year]. doi:10.1136/bcr-2018 225737

\section{DESCRIPTION}

A 67-year-old man with medical history significant for hypertension and hyperlipidaemia was found on screening colonoscopy to have a large, polypoid adenomatous polyp of the distal descending colon not amenable to colonoscopic resection. $\mathrm{He}$ underwent a robotic sigmoid colon resection with primary anastomosis. Postoperatively the patient developed persistent abdominal distention, nausea and had no passage of flatus or bowel movements after 7 days which was initially attributed to ileus. Cross-sectional CT revealed a closed-loop small bowel obstruction secondary to an incarcerated hernia at the right lateral $8 \mathrm{~mm}$ robotic trocar site with surrounding subcutaneous emphysema (figure 1). On physical examination, there was no palpable bulge or overlying erythema along the previous incision. The patient was brought back to the operating room and underwent a diagnostic laparoscopy utilising the prior robotic incisions. On exploration, the incarcerated small bowel loop was easily reduced with gentle traction and appeared viable with healthy peristalsis and no serosal injury. The fascial defect was then closed primarily. The remainder of his hospital course was uncomplicated with normalisation of his bowel function and he was discharged to short-term rehabilitation.

Trocar site hernias (TSH) represent a rare complication following laparoscopic and robotic surgery. Data demonstrates an incidence of $0.6 \%$ after colorectal surgery for cancer. ${ }^{1}$ The occurrence of TSH may be related to multiple technical factors including port location, trocar design, insertion technique, intraoperative manipulation and fascial closure. Additional patient-related factors exist including body habitus, age and presence of wound infection. Most TSH occurs at the site of midline trocars with umbilical sites being most common. This is believed to be due to the single fascial layer at the linea alba and the embryological anatomy of the umbilicus, which creates a natural defect at this location. The umbilicus is also where the largest trocar is typically placed with increased manipulation in specimen retrieval and camera movement leading to fascial defect extension. Lateral trocar sites are intrinsically less susceptible to TSH development and traditionally do not mandate fascial closure. A meta-analysis performed by Owens et al reviewed 11699 patients who underwent minimally invasive gastrointestinal surgeries. Despite having no universal consensus on facial defect repair, the general recommendation is closure of all trocars $\geq 10 \mathrm{~mm}$, and closure of defects $>5 \mathrm{~mm}$ where ports have been subject to excessive manipulation. ${ }^{2}$ Additional manoeuvres may also be employed to decrease

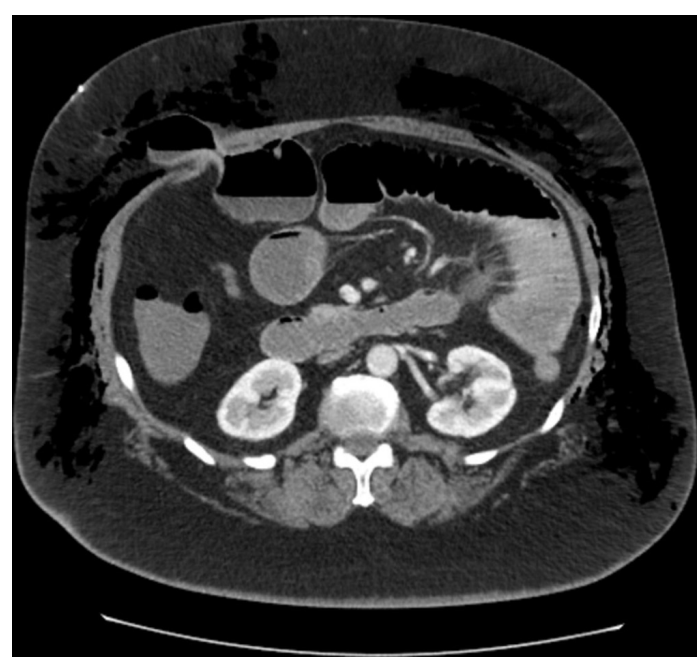

Figure 1 Closed-loop obstruction secondary to right lateral $8 \mathrm{~mm}$ trocar site hernia with subcutaneous emphysema.

TSH occurrence such as gentle disinflation of pneumoperitoneum to prevent bowel from being drawn into the defect, digital examination of all trocar sites to evaluate for abdominal contents and sufficient muscle relaxation until closure is complete.

While rare, TSH is an important complication to consider following minimally invasive surgery. Closure of larger midline trocar sites is generally recommended and a low threshold for postoperative follow-up must be maintained if there is clinical concern for obstruction.

\section{Learning points}

- Trocar site hernias most commonly occur at midline with umbilical sites being most common.

- Fascial defects $>10 \mathrm{~mm}$ are generally recommended for primary closure to prevent hernia formation or $5 \mathrm{~mm}$ sites with increased manipulation.

- Clinical symptoms consistent with bowel obstruction following minimally invasive surgery should prompt workup for trocar site hernias.

Contributors All authors have equally contributed to the planning, conducting and authorship of this submission.

Funding The authors have not declared a specific grant for this research from any funding agency in the public, commercial or not-for-profit sectors.

Competing interests None declared.

Patient consent Obtained. 


\section{Images in...}

Provenance and peer review Not commissioned; externally peer reviewed.

(c) BMJ Publishing Group Ltd (unless otherwise stated in the text of the article) 2018. All rights reserved. No commercial use is permitted unless otherwise expressly granted.

\section{REFERENCES}

1 Lumley J, Stitz R, Stevenson A, et al. Laparoscopic colorectal surgery for cancer: intermediate to long-term outcomes. Dis Colon Rectum 2002;45:867-72.

2 Owens M, Barry M, Janjua AZ, et al. A systematic review of laparoscopic port site hernias in gastrointestinal surgery. Surgeon 2011;9:218-24.

Copyright 2018 BMJ Publishing Group. All rights reserved. For permission to reuse any of this content visit

http://group.bmj.com/group/rights-licensing/permissions.

BMJ Case Report Fellows may re-use this article for personal use and teaching without any further permission.

Become a Fellow of BMJ Case Reports today and you can:

- Submit as many cases as you like

- Enjoy fast sympathetic peer review and rapid publication of accepted articles

- Access all the published articles

Re-use any of the published material for personal use and teaching without further permission

For information on Institutional Fellowships contact consortiasales@bmjgroup.com

Visit casereports.bmj.com for more articles like this and to become a Fellow 